\title{
KETIDAKADILAN GENDER \\ DALAM KEHIDUPAN \\ PEREMPUAN TIONGHOA \\ DI KOTA MEDAN
}

\author{
Rudiansyah \\ Departemen Kajian Budaya Fakultas Ilmu Budaya \\ Universitas Padjadjaran
}

\begin{abstract}
Research of gender study Tionghoa in Medan city commenced from basic question whether or not the life of Tionghoa society in Medan city in all aspects (social, culture, economy and politic) are based on impartial gender principle. Qualitative, quantitative, observation, indepth interview, questionare methods and library research are applied to study the above case. The result shows that the live Tionghoa society in Medan city is still influenced by traditional values, culture and life orientation that lead to gender inequality. These values appear from patrilineal kinship system: women social status with man sub-ordinate, women activities are more in domestic structure and their productive activities are limited to home anvironment (stall, shop, service, home industry).
\end{abstract}

Keywords : Tionghoa Women; Gender; Cultural Construction and Stereotypes.

\section{PENDAHULUAN}

Dalam budaya Tionghoa kedudukan laki-laki dan wanita merupakan personifikasi dari unsur "Yin" dan "Yang", yaitu unsur-unsur yang bersifat aktif dan unsur-unsur yang bersifat pasif. Dalam hal ini "Yang" (aktif) dipersepsikan sebagai laki-laki dan "Yin" (pasif) dipersepsikan sebagai perempuan. Personifikasi tersebut kemudian dibingkai dalam struktur sosial dengan sistem kekerabatan patrilineal dimana keluarga sebagai lembaga dipimpin seorang laki-laki, sehingga laki-laki lebih memiliki kekuasaan daripada perempuan.
Demikian juga kewajiban utama lakilaki dalam pemenuhan kebutuhan keluarga atau rumah tangga, sedangkan perempuan sifatnya hanya membantu. Dampaknya adalah laki-laki cenderung terlibat dalam sektor perekonomian modern skala luas, sedangkan perempuan cenderung berada dalam sektor domestik atau sektor perekonomian dalam skala kecil dan lingkungan tempat tinggal (Vincent, 2011:5).

\section{LANDASAN TEORI}

Menurut feminis, perempuan harus mampu memperlihatkan kekuatan melalui kecantikan dan kelembutan mereka. Perempuan 
tidak lagi harus meniru maskulinitas laki-laki untuk mendapatkan kekuatan dan kesejajaran. Artikel "Girl Power" (dalam Taylor, 2003) mengarahkan perempuan untuk lebih suka bermain atas kesadaran sendiri dalam penggunaan pakaian dan perhiasan. Di sini fashion dianggap sebagai representasi diri perempuan.

Femininitas baru, mengarahkan perempuan untuk dapat menikmati tubuhnya. Pakaian dan perhiasan yang mereka pakai bukan lagi menjadi bentuk femininitas perempuan, tetapi lebih mengarah kepada ekspresi diri mereka. Misalnya, ketika prempuan menggunakan sepatu hak tinggi yang bukan lagi merupakan bentuk praktik disiplin tubuh yang menyakitinya. Mereka kini dapat menikmati sepatu hak tingginya sebagai ekspresi dirinya yang ingin tampil lebih cantik dan menarik. Selain itu, perempuan juga dapat mengeksplorasi wajahnya dengan tata rias yang ia pakai. Dengan berbagai alat tata rias, perempuan dapat melukis wajahnya sesuai dengan ekspresi yang ia inginkan. Bukan lagi dianggap sebagai pendisiplinan tubuh atau untuk menutupi kekurangan dari tubuhnya. "Girl Power" juga mempertentangkan feminis yang sering menggap dirinya sebagai pusat-korban (Taylor, 2003). Maksud pusat korban di sini adalah bagi feminis, perempuan selalu menjadi korban laki-laki. Perempuan termarjinalkan dari sistem patriarki. Pemarjinalan prempempuan ini dibentuk oleh budaya yang patriarki. Sebagai contoh, di Indonesia, laki- laki harus menjadi kepala rumah tangga. Artinya laki-laki harus bekerja untuk menghidupi rumah tangga mereka. Laki-laki juga diharapkan dapat mendidik istrinya. Sedangkan perempuan dituntut untuk dapat melayani suami dengan sebaik mungkin, juga dapat mematuhi segala aturan yang dibuat oleh suaminya. Maka dari itu, karena laki-laki tidak ingin penghasilannya lebih sedikit dari istrinya, mereka melarang istrinya untuk bekerja di luar. Mereka menuntut istrinya untuk bekerja di rumah, dengan memasak, membersihkan rumah, dll. Selain itu, karena suami bertugas untuk mendidik istrinya, laki-laki harus lebih pintar dari perempuan. Biasanya laki-laki tidak mau istrinya sekolah lebih tingga dari mereka. Itulah gambaran mengapa para feminis menyebut perempuan sebagai korban laki-laki.

Berbeda dengan femininitas baru, mereka menentang pendapat para feminis tersebut. Feminis baru mengarahkan perempuan untuk menikmati dan menjadikan kekuatan perempuan ketika perempuan dilarang bekerja di luar maupun dilarang untuk bersekolah lebih tinggi. Ketika perempuan memasak untuk suaminya, perempuan harus merasakan kenikmatan dari kegiatan memasak tersebut. Misalnya, dengan menyajikan masakan yang enak, kekuatan perempuan akan muncul ketika suaminya menyukai masakannya. Femininitas baru juga dibahas dalam artikel "A Vogue" yang dikutip oleh Susan Hopkin dalam "The Politics of Pretty" 
menyebutkan bahwa sekarang, perempuan memperlihatkan kepercayaan diri yang merangkul ornamen femininitas (Taylor, 2003: 189). Hal ini membuat perempuan lebih nyaman untuk membaca majalah perempuan, mempelajari teori feminis yang kompleks, serta merasakan kenikmatan untuk melalakukan praktik femininitas (Taylor, 2003: 189). Menurut femininitas baru, kini perempuan dapat menikmati dirinya ketika mengeksplorasi dirinya ke dalam bentuk feminintas. Perempuan tidak akan merasa ragu untuk menampilkan femininitas sebagai kekuatannya.

Menurut Joan Rivers (dalam Taylor, 2003) dalam femininitas, teori feminis dianggap sebagai tampilan femininitas untuk meredakan ketakutan maskulin tentang kehadiran perempuan di ranah publik. Namun, berbeda dengan femininitas baru, mereka menganggap perempuan sepadan dengan laki-laki (Taylor, 2003). Sehingga, teori feminis tidak lagi dijadikan bentuk perlawanan terhadap budaya patriakal. Bagi femininitas baru, Fashion yang digunakan oleh perempuan tidak lagi bertujuan untuk menentang maskulinitas, melainkan sebagai citra diri mereka sendiri (Taylor, 2003). Bagi femininitas baru, untuk menunjukkan kekuatan perlawanan perempuan terhadap laki-laki, perempuan tidak perlu berpenampilan maupun berperilaku seperti laki-laki. Perempuan juga tidak perlu mengerjakan pekerjaan yang biasa dilakukan oleh laki-laki. Dengan menampilkan sisi feminin, perempuan dapat menunjukkan kekuatannya untuk melakukan perlawanan terhadap budaya patriarki. Mereka tidak perlu melakukan pekerjaan yang dilakukan oleh laki-laki. Dengan melakukan pekerjaan perempuan, mereka juga dapat menampilkan kekuatan yang dimiliki oleh mereka. Menurut femininitas baru, citra femininitas harus dipulihkan, tidak boleh diremehkan, dan menjadikan investasi feminis menjadi aktifitas legal (Taylor, 2003). Maksudnya adalah, kegiatan perempuan untuk menjadikan dirinya tampil feminin, tidak lagi dianggap sebagai sebuah kegiatan yang dianggap menyakiti dirinya. Femininitas kini harus dianggap sebagai sebuah kenyamanan perempuan dalam mengekspresikan diri sebagai perempuan. Diet, merias wajah, merawat wajah dan tubuh, operasi wajah dan tubuh tidak lagi harus dianggap sebagai penyiksaan terhadap perempuan, tetapi dianggap sebagai kenikmatan perempuan untuk bereksplorasi dengan tubuhnya. Taylor berpendapat bahwa perempuan tidak lagi merasa dapat diremehkan atau dimarjinalkan melalui pakaian mereka (2003). Dengan menggunakan rok dan pakaian berbunga-bunga, perempuan tidak boleh dianggap lemah. Untuk menjadi kuat, perempuan tidak perlu berpakaian dan bertingkah laku seperti laki-laki. Untuk mendapat kesejajaran dengan laki-laki, 
perempuan tidak harus memaksakan dirinya untuk menjadi laki-laki, karena perempuan memiliki kekuatan yang berbeda dengan lakilaki.

\section{TAHAPAN REVIEW}

\section{Gender pada Masyarakat Tionghoa di Kota Medan}

Gender merupakan seperangkat peran yang dikenakan pada jenis kelamin seseorang. Pada gender ini sangat dipengaruhi oleh tingkat sosial, usia serta letar belakang budaya etnis. Gender di lingkungan masyarakat Tionghoa secara umum terkait dengan konsep pemikiran mereka tentang alam semesta. Konsep alam dalam budaya Tionghoa adalah menyatunya unsur "Yang" dan "Yin". Yang merupakan simbol dari kekuatan, keperkasaan, keaktifan, cahaya (siang), panas , matahari, arah selatan. Sedangkan Yin merupakan simbol dari segala hal yang bersifat pasif, dingin, gelap (malam), bulan, arah utara, yang semuanya merupakan sifat-sifat dasar perempuan. Berdasarkan konsep "Yang" dan "Yin", tampak telah ada pemisahan sifat dan peran anatara sifat laki-laki dan perempuan. Walaupun demikian perbedaan sifat "Yang" dan "Yin" akan menjaga harmoni alam dan kehidupan (Lasiyo, 1995:78).

Pengaruh budaya dan tradisi yang hidup dalam masyarakat Tionghoa juga mempengaruhi peran gender mereka. Kepercayaan dan ajaran moral Taoisme dan Konfusianisme telah mengajarkan keharmonisan hubungan-hubungan antara anggota keluarga dan hubungan-hubungan dalam masyarakat. Taoisme mengajarkan hubungan yang harmonis antara orang tua dengan anak, suami dengan istri, raja dengan rakyat serta saudara yang lebih tua dengan saudara yang lebih muda. Konfusianisme juga mengatur hubungan-hubungan sosial secara harmonis, antara pemerintah dengan para menteri dan rakyat, ayah dengan anak laki-laki, saudara lakilaki tertua dengan yang lebih muda, suami dengan istri dan teman dengan istri.

Dari ajaran Taoisme dan Konfusianisme terlihat jelas bahwa kedudukan perempuan Tionghoa mempunyai derajat yang sama dengan anggota keluarga yang lain. Dalam hal ini, yang cukup mempengaruhi peran gender dalam masyarakat Tionghoa adalah bahwa dalam Konfusianisme menganut sistem patrilineal. Kedudukan ayah dan anak laki-laki sangat penting dalam keluarga, hal ini di karenakan anak laki-laki tertua akan menggantikan keudukan seorang ayah apabila ayahnya meninggal. Dalam keluarga Tionghoa, warisan hanya diberikan kepada anak lakilaki saja, dan anak laki-laki tertua akan mendapatkan warisan yang lebih banyak. Bila dasar-dasar hubungan sosial seperti dalam ajaran Taoisme dan Konfusianisme dijalankan, khususnya yang berkaitan dengan kehidupan keluarga, maka hal ini diyakini dapat menjalin hubungan baik dengan 
keluarga dan masyarakat luas (Mulyana, 2006:44).

Keluarga merupakan lembaga yang sangat penting, karena pada hakekatnya keluarga merupakan tempat kelahiran seseorang. Penghormatan terhadap keluarga juga terkait dengan etik bahwa lakilaki harus menghormati istrinya sebagai orang yang telah melahirkan. Walaupun demikian, bila seorang istri tidak dapat melahirkan anak laki-laki, maka suaminya boleh menikah lagi. Lambang penghormatan terhadap perempuan Tionghoa dapat dilihat dalam kehidupan sehari-hari, yaitu dilaksakannya pemujaan terhadap Dewi Kuan Im yang di yakini menjadi simbol kasih sayang pada masyarakat Tionghoa (Agnes, 2013:2).

Dari fakta-fakta yang hidup di dalam masyarakat Tionghoa, maka dapat dikatakan bahwa di satu sisi perempuan Tionghoa tampak mempunyai kedudukan yang sama dengan laki-laki tetapi di sisi lain sebagai pelengkap untuk dapat memperkuat kedudukan laki-laki melalui sistem kekerabatan patrilineal.

Seperti di daerah lainnya, masyarakat Tionghoa di Kota Medan terdiri dari golongan Tionghoa totok dan golongan Tinghoa peranakan. Secara umum kedua golongan ini tampak tidak berbeda, tetapi secara khusus ada perbedaan-perbedaan mendasar yang berkaitan dengan tradisi dan budaya, terutama budaya dan tradisi yang berkaitan dengan kedudukan perempuan Tionghoa.
Agar pembahasan tentang kedudukan perempuan Tionghoa ini dapat terfokus, maka akan dibahas secara khusus kedudukan perempuan di lingkungan masyarakat Tionghoa Totok dan Tionghoa Peranakan.

\section{Kedudukan Perempuan Tionghoa Totok}

Di Kota Medan jumlah orang Tionghoa totok lebih sedikit dibandingkan dengan orang Tionghoa peranakan. Walaupun demikian, budaya dan tradisi yang hidup di lingkungan masyarakat Tionghoa totok dari masa lalu masih membekas sampai sekarang. Orangorang Tionghoa totok di Kota Medan dalam kehidupannya sehari-hari masih dipengaruhi oleh budaya dan tradisi dari negeri asalnya. Budaya dan tradisi yang mereka lakukan terkait erat dengan nilai-nilai ajaran Taoisme dan Konfusianisme.

Berdasarkan ajaran-ajaran falsafah Taoisme dan Konfusianisme yang menjadi dasar kepercayaan masyarakat Tionghoa, kedudukan perempuan dalam keluarga merupakan bagian dari anggota keluarga yang lain. Kedudukan antara laki-laki dan perempuan sebagai anggota keluarga telah diatur dalam tata hubungan sosial yang harmonis sesuai dengan posisinya masing-masing, dimana laki-laki sebagai panutan dan perempuan sebagai pengikut. Bagi masyarakat Tionghoa keluarga merupakan lembaga terpenting yang harus dijaga keharmonisannya, karena dalam keluarga akan dilahirkan manusia- 
manusia yang akan melanjutkan kehidupan, tentunya dalam upaya menciptakan keharmonisan hubungan antara suami dengan istri, ayah dengan anak serta hubungan kakak dengan adik (Lasiyo, 1995:81).

Dinamika dalam keluarga Tionghoa mengikuti pola gerak alam yang mengandung unsur "Yang" dan "Yin", yaitu unsur-unsur aktif dan pasif sebagai simbol yang mewakili sifat laki-laki dan perempuan. Sebagai suatu lembaga, keluarga harus mempunyai pimpinan yang dapat melindungi dan mengayomi keluarga. Dalam hal ini yang mendapat peran sebagai pemimpin adalah ayah. Dengan demikian, struktur kekerabatan yang dianut oleh keluarga Tionghoa totok adalah patrilineal. Pada sistem kekerabatan patrilineal gelar keluarga atau "She" diturunkan sebagai garis keturunan ayah, sehingga peran ayah dan anak laki-laki sangat penting. Anak lakilaki tertua akan menggantikan kedudukan seorang ayah sebagai kepala keluarga apabila ayahnya telah meninggal dunia, dan dia pula yang akan menerima warisan lebih banyak dibandingkan saudara yang lainnya. Dalam keluarga Tionghoa totok, anak perempuan tidak mendapatkan warisan, karena setelah menikah dia akan ikut dan menjadi tanggungjawab keluarga suaminya. Selain itu, yang berhak mengurus dan memelihara abu leluhur serta melaksanakan upacara penghormatan terhadap arwah leluhur adalah anak laki-laki (Darwis, 2010:67).
Pada masa lalu, perempuan di lingkungan keluarga Tionghoa totok apabila sudah memasuki usia dewasa, mereka dipingit dan tidak bebas lagi melakukan kegiatan di luar rumah sampai saat mereka menikah. Tradisi ini menyebabkan perempuan Tionghoa totok tidak mendapatkan pendidikan yang memadai. Mereka hanya mendapat pendidikan dari keluarga yang berkaitan, yaitu dengan pendidikan moral, budaya, tradisi, agama dan hal-hal yang berkaitan dengan pengelolahan rumah tangga dan keluarga. Hal ini berbeda dengan laki-laki yang mendapat kebebasan dalam memperoleh pendidikan. Laki-laki dari Tionghoa totok dapat menempuh pendidikan di sekola $\mathrm{Hoa}$ Hwee Koan yang sudah berdiri sejak tahun 1900 di Indonesia (Agnes, 2013:42).

Pernikahan dalam masyarakat Tionghoa totok merupakan masa yang penting, karena kedewasaan seseorang dilihat dari apakah ia sudah menikah atau belum. Oleh karena itu upacara pernikahan dibuat secara besar-besaran dan mengesankan. Pada keluarga Tionghoa totok, pernikahan diatur oleh orang tua kedua belah pihak. Sebelum acara pernikahan berlangsung, kedua mempelai tidak saling mengenal, dan baru mengenal pada saat upacara pernikahan. Namun saat ini, jenis perjodohan seperti ini sudah jarang terjadi.

Sebelum hari pernikahan, orang tua pihak laki-laki akan mengantar ang-pao yaitu uang yang dibungkus kertas merah yang sering 
disebut sebagai uang susu, yang dimaksudkan sebagai uang pengganti biaya selama perempuan dalam pengasuhan orangtuanya. Apabila pihak dari perempuan berasal dari keluarga yang kaya atau berkecukupan biasanya mereka akan menolak secara halus pemberian $a n g-$ pao tersebut, karena takut dianggap menjual anak perempuannya. Apabila keluarga perempuan berasal dari keluarga kurang mampu, maka pemberian ang-pao diterima dengan suka cita. Selain ang-pao, biasanya mereka juga membawa barangbarang pemberian yang lain berupa pakaian dan perhiasan (Agnes, 2013:48).

Apabila perempuan menikah dengan anak laki-laki tertua, maka setelah menikah ia sebagai istri harus mengikuti suaminya dan tinggal menetap di rumah orangtua suami (mertua), karena terkait dengan kewajiban suaminya untuk memelihara abu leluhur. Di dalam rumah tangga mertua, istri harus patuh dan tunduk mengikuti aturan dan tata tertib yang berlaku. Ia juga harus mendampingi dan membantu suaminya dalam menjalankan kewajibannya sebagai anak terhadap orang tuanya. Perempuan yang hidup dalam rumah tangga mertuanya dituntut dapat menyesuaikan diri dan mempunyai rasa toleransi yang tinggi. Proses penyesuaian diri ini seringkali sangat berat, dikarenakan aturan-aturan yang cukup menekan. Bahkan sering terjadi konflik antara menantu perempuan dengan ibu mertua. Walaupun demikian, seburuk apapun hubungan antara menantu perempuan dan mertua hubungan ini tidak dapat putus, karena menantu sudah dianggap sebagai anak oleh mertua. Kelak apabila suaminya meninggal, ia masih menjadi tanggungan keluarga suami karena sudah dianggap sebagai anak sendiri. Seandainya perempuan yang sudah menjadi janda ini akan menikah lagi, maka keluarga almarhum suaminya yang akan mengatur dan melaksanakan pernikahan berikutnya (Agnes, 2013:82).

Dalam tradisi orang Tionghoa totok, perceraian sangat ditabukan karena di anggap akan mencemarkan nama baik keluarga. Kalaupun sampai terjadi perceraian, biasanya karena alasan istri tidak bisa melahirkan anak laki-laki atau istri tidak mau hidup bersama dengan istri muda suaminya dalam satu rumah tangga. Kadang kala, istri juga menganjurkan suaminya menikah lagi karena tidak bisa melahirkan seorang anak laki-laki. Dalam tradisi Tionghoa totok, seorang suami hanya boleh mempunyai satu orang istri, tetapi disamping istri pertamanya ia juga boleh menikah dengan perempuan lain sebagai istri muda. Tidak jarang istri pertama tinggal bersama-sama dengan istri muda dalam satu rumah tangga. Istri pertama biasanya menjadi istri utama yang mengtur seluruh urusan rumah tangga dan mendampingi suami dalam kegiatan-kegiatan sosial dan pertemuan-pertemuan keluarga, sedangkan istri kedua bertugas sebagai pembantunya dalam urusanurusan rumah tangga. Dewasa ini 
sebagian besar orang Tionghoa totok menganut sistem perkawinan monogami (Agnes, 2013:101).

\section{Kedudukan Perempuan Tionghoa Peranakan}

Berbeda dengan kedudukan Tionghoa totok, kedudukan Tionghoa peranakan di Kota Medan lebih bersikap akomodatif terhadap budaya dari luar lingkungannya, terutama budaya barat dan budaya daerah sekitarnya. Meskipun demikian, sebagian dari mereka kadang kala masih cukup fanatik dalam mengikuti budaya dari tanah leluhurnya. Struktur kekerabatan pada masyarakat Tionghoa peranakan sudah tidak terlalu berorientasi pada sistem kekerabatan patrilineal, tetapi sudah menganut sisitem kekerabatan bilateral. Perubahan ini kemungkinan disebabkan karena golongan Tionghoa peranakan sudah berada di Kota Medan selama kurang lebih 3-4 generasi dan sebagian dari mereka bukan keturunan asli Tionghoa, mereka tidak dilahirkan di Tiongkok dan bukan berasal dari ayah atau ibu asli Tionghoa (Agnes, 2013:119).

Dalam keluarga Tionghoa peranakan yang menganut struktur kekerabatan bilateral ada anggapan bahwa kedudukan perempuan sama pentingnya dengan kedudukan lakilaki, sehingga tidak menjadi masalah jika dalam keluarga tidak ada seorang anak laki-laki. Anak perempuan juga akan mendapatkan warisan yang sama dengan saudara laki-laki. Dalam keadaan tertentu, anak perempuan juga mendapat amanah dan tugas untuk merawat abu leluhur serta melaksanakan upacara-upacara penghormatan terhadap arwah leluhur. Kedudukan Tionghoa peranakan lebih memilih bentuk keluarga kecil daripada keluarga besar dan luas.

Tradisi pingitan yang berlaku pada Tionghoa totok, tidak berlaku pada Tionghoa peranakan. Perempuan dari Tionghoa peranakan lebih leluasa melakukan kegiatan di luar rumah. Mereka juga mendapatkan pendidikan yang cukup memadai, baik itu di sekolah Tionghoa, sekolah Belanda maupun sekolah Umum Negeri, bahkan cukup banyak perempuan dari golongan Tionghoa peranakan yang mencapai pendidikan tinggi (Agnes, 2013:89).

Dalam masalah pernikahan, keluarga Tionghoa peranakan masih terkait dengan tradisi-tradisi lama walaupun tidak seketat dan sekaku aturan yang berlaku pada keluarga Tionghoa totok. Pernikahan dalam keluarga Tionghoa peranakan mengikuti aturan-aturan agama yang dianut dan tradisi yang masih berlaku. Walaupun demikian ada beberapa larangan dalam pernikahan keluarga Tionghoa peranakan, yaitu pernikahan antara orang-orang yang mempunyai nama keluarga atau "she" yang sama, tetapi dewasa ini aturan-aturan tersebut sudah mulai mengendur. Sejauh pernikahan itu bukan antara kerabat dekat, walaupun mereka satu "she", diperbolehkan. Yang perlu diperhatikan adalah larangan 
perempuan menikah dengan laki-laki yang mempunyai hubungan kekerabatan tetapi dari generasi yang lebih muda, misalnya anak dari saudara (keponakan) atau anak dari sepupu. Pernikahan antara perempuan dengan laki-laki yang sederajat tetapi dari generasi yang lebih tua, misalnya saudara sepupu ibu, diperbolehkan. Aturan-aturan dalam pernikahan seperti tersebut di atas, menunjukkan bahwa suami dari keluarga Tionghoa peranakan tidak menghendaki istrinya yang lebih tua atau lebih tinggi derajat kekerabatannya (Agnes, 2013:129).

Setelah menikah, istri tidak harus tinggal menetap di kediaman orangtua (mertua). Keluarga baru ini bebas menentukan akan tinggal dan menetap dimana saja. Apakah mereka akan tinggal di rumah orangtua sendiri, di rumah mertua atau di rumah sendiri. Hubungan kekerabatan dari pihak ibu dan istri sama dekatnya dengan hubungan kekerabatan dari pihak ayah atau suami.

Dalam keluarga Tionghoa peranakan, keharmonisan keluarga menjadi hal yang sangat diutamakan. Dalam keluarga juga mulai dikembangkan sikap-sikap demokratis. Masalah-masalah penting dalam keluarga diputuskan berdasarkan musyawarah seluruh anggota keluarga, tetapi keputusan terakhir tetap berada di tangan ayah sebagai kepala keluarga. Tidak jarang dalam keluarga Tionghoa peranakan peran ibu lebih dominan dibandingkan dengan ayah. Hal ini bukan berarti berkurangnya rasa hormat ibu terhadap ayah, tetapi ada hal-hal atau masalah-masalah dalam keluarga yang memang kurang dikuasai seorang ayah sehingga harus diambil alih oleh seorang ibu. Dewasa ini bukan hal tabu lagi bila seorang ayah mengerjakan pekerjaan domestik rumah tangga dan ibu melakukan pekerjaan-pekerjaan yang dipandang cukup berat.

Perceraian di lingkungan keluarga Tionghoa peranakan sangat dihindari. Kalaupun terjadi perceraian, alasannya bukan hanya karena istri tidak bisa melahirkan seorang anak laki-laki, tetapi ada alasan-alasan yang lebih kompleks. Perceraian harus diselesaikan secara kekeluargaan dan sesuai dengan aturan-aturan agama yang dianut. Kecenderungan laki-laki dari lingkungan Tionghoa peranakan untuk melakukan poligami sangat rendah dibandingkan dengan lakilaki Tionghoa totok, karena mereka banyak yang sudah menganut agama Katholik atau Kristen, yang tidak membenarkan poligami (Agnes, 2013:143).

\section{Perubahan Kedudukan Perempuan Tionghoa di Kota Medan}

Sebelum abad ke-20 perempuan tionghoa di Kota Medan, baik dari golongan Tionghoa totok maupun Tionghoa peranakan belum memperoleh pendidikan yang layak. Pendidikan yang mereka peroleh hanyalah berupa pendidikan dari lingkungan keluarga, yaitu pendidikan yang berkaitan dengan moral kesusilaan, etika pergaulan, agama dan kepercayaan, budaya dan 
tradisi, pengelolahan rumah tangga serta keterampilan-ketrampilan lain yang bersifat ke ibuan.

Setelah sekolah Tiong Hoa Hwee Koan, yaitu sekolah khusus untuk orang Tionghoa dibangun pada tahun 1900an, barulah perempuan Tionghoa mendapat kesempatan memperoleh pendidikan formal. Walaupun sudah ada sekolah khusus untuk orang Tionghoa, tetapi perempuan Tionghoa yang masuk sekolah ini masih sangat sedikit. Hal ini disebabkan aturan adat yang tidak memberi kebebasan kepada perempuan Tionghoa untuk bergerak di luar rumah, khususnya perempuan di lingkungan masyarakat Tionghoa totok.

Seiring dengan perkembangan zaman, perempuan Tionghoa semakin banyak yang menempuh pendidikan di sekolah Tiong Hoa Hwee Koan. Bahkan pada masa itu sudah ada perempuan tionghoa peranakan yang bersekolah di Hollands Chinese School, yaitu sekolah Belanda khusus untuk orang-orang Tionghoa. Sekolah ini menjadi salah satu pilihan dari Tionghoa peranakan dalam menempuh pendidikan. Ketika Jepang berkuasa di Indonesia, sekolah-sekolah Belanda ditutup sehingga hanya sekolah Tionghoa yang menjadi satu-satunya pilihan bagi masyarakat Tionghoa, baik Tionghoa totok maupun Tionghoa peranakan (Mosse, 1996:65).

Setelah kemerdekaan Indonesia, sekolah Tionghoa masih menjadi pilihan utama bagi masyarakat Tionghoa dalam menempuh pendidikan sampai terjadinya peristiwa G30S. Setelah tahun 1965 pemerintah mengambil kebijakan untuk menutup sekolah Tionghoa sehingga semua orang Tionghoa peranakan masuk sekolah negeri atau sekolah swasta yang dikelola oleh sebuah yayasan Katholik dan Kristen. Pendidikan barat telah menyebabkan perubahan pada golongan Tionghoa peranakan, terutama pada kehidupan perempuan, yaitu perubahan dalam pemikiran, orientasi budaya dan interaksi sosial dengan masyarakat. Konsep-konsep tentang kebebasan, demokrasi, emansipasi, hak asasi dan sebagainya, yang mereka peroleh dari bangku sekolah telah menimbulkan kesadaran baru, bahwa perempuan juga mempunyai hak untuk maju dan diharapkan dapat berpartisipasi dalam masyarakat luas. Dengan demikian, aturanaturan adat yang mengekang kebebasan mereka secara bertahap dan perlahan mulai ditinggalkan. Bahkan tradisi pingitan dan perjodohan sudah tidak dikenal lagi oleh generasi baru Tionghoa peranakan dewasa ini (Yusin, 2000:56).

Selain itu prinsip-prinsip agama Katholik dan agama Kristen yang mereka kenal dari bangku sekolah juga telah membawa mereka menjadi pemeluk agama tersebut. Prinsipprinsip agama Katholik dan Kristen yang mereka anut tidak membedakan kedudukan antara lakilaki dan perempuan serta menempatkan masing-masing individu dalam peran dan posisinya. Hal ini juga telah merubah pola pikir dan pandangan perempuan 
Tionghoa peranakan, yaitu bahwa kedudukan mereka sejajar dengan laki-laki sesuai dengan kodratnya. Dalam kehidupan sehari-hari selain melaksanakan kegiatan sesuai dengan aturan agama yang dianut, mereka juga masih melakukan kegiatan yang berkaitan dengan tradisi dan budaya laluhur, walaupun sudah tidak sesering dan serumit zaman dahulu.

Sejalan dengan kemajuan zaman yang dicapai oleh perempuan Tionghoa, telah menjadi perubahan dalam pola hubungan kemasyarakatan, yaitu mereka lebih terbuka dalam menerima perubahanperubahan dan terbuka dalam berinteraksi dengan masyarakat di luar lingkungannya. Dalam berinteraksi dengan masyarakat setempat mereka menggunakan bahasa Indonesia maupun bahasa daerahnya. Pada masa-masa sebelumnya mereka banyak menggunakan bahasa ibu atau bahasa Hokkien dalam berkomunikasi dengan masyarakat sekitarnya (Puspa, 1990:38).

Perubahan di bidang sosial budaya juga tampak dari penampilan dan cara berbusana perempuan Tionghoa. Sebelum mereka bersentuhan dengan budaya barat, mereka menggunakan busana tradisional "Cheong-Sam" terutama perempuan Tionghoa totok, dan wanita Tionghoa peranakan menganakan busana "Kabaya Encim." Dewasa ini perempuan Tionghoa sudah berbusana sesuai perkembangan mode serta mengikuti cara berbusana ala barat.
Aktivitas perempuan Tionghoa di bidang sosial merupakan salah satu bentuk kepedulian mereka untuk membantu masyarakat sekitarnya dalam masalah pendidikan, agama, kepercayaan, ekonomi, dan sebagainya. Dewasa ini perempuan Tionghoa banyak yang aktif di perkumpulan gereja, perkumpulan kelompok agama atau kepercayaan lain seperti perkumpulan Rasa Darma, Tri Darma, Sam Kauw Hwee (perkumpulan tiga pemeluk agama yaitu Budha, Konfusianisme, dan Taoisme) serta perkumpulan pemeluk kepercayaan lainnya (Darwis, 2010:44).

Kesempatan-kesempatan yang lebih terbuka dalam berhubungan dan berinteraksi dengan masyarakat luas memberikan dampak lain kepada perempuan Tionghoa dalam melakukan aktivitas ekonomi. Mereka mempunyai kesempatan yang lebih luas untuk bergerak di bidang usaha, perdagangan dan bidang pekerjaan lain yang diharapkan dapat memperoleh keuntungan serta dapat menopang perekonomian keluarga. Lingkungan keluarga yang mempunyai latar belakang sebagai pedagang serta karakter yang terbentuk dari ajaranajar Buddha, Konfusianisme, dan Taoisme yang mengajarkan sikap rajin, tekun, teliti, ulet, hemat, serta bekerja keras, telah mengantarkan perempuan Tionghoa dalam kemajuan di bidang ekonomi. Dewasa ini bukan hanya bidang perdagangan saja yang bisa ditekuni oleh perempuan Tionghoa, mereka juga mempunyai profesi lain seperti 
dokter, notaris, ahli hukum, pendidik, pegawai negeri, pegawai perusahaan atau industri dan lain sebagainya. Tujuan utamanya tidak lagi sekedar mencari nafkah, tetapi lebih luas yaitu untuk mengembangkan diri dan memanfaatkan ilmu pengetahuannya (Darwis, 2010:48).

Dalam kehidupan politik, aktivitas perempuan Tionghoa tidak terlalu tampak. Hal ini disebabkan karena perjalanan sejarah yang kurang melibatkan orang-orang Tionghoa dalam bidang politik di masa lalu, terutama yang berkaitan dengan gerakan $30 \quad$ September 1965. Walaupun demikian, sebagian besar golongan Tionghoa peranakan, termasuk perempuannya sudah mempunyai kesadaran untuk menjadi Warga Negara Indonesia (WNI). Dengan menjadi WNI, mereka mempunyai hak dan kewajiban yang sama dengan WNI lainnya, terutama dalam bidang politik. Salah satu bentuk partisipasi perempuan Tionghoa dalam bidang politik adalah turut serta dalam pemilihan umum dan menjadi pendukung partai yang dianggap sesuai dengan aspirasinya (Yusin, 2000:58).

\section{Aktivitas Sosial Perempuan Tionghoa di Kota Medan}

Perempuan Tionghoa di Kota Medan selain disibukkan dengan urusan rumah tangga dan kegiatan ekonomi dalam rangka memenuhi kebutuhan rumah tangga, juga melakukan kegiatan-kegiatan di luar lingkup rumah tangganya dalam berbagai organisasi sosial. Mereka banyak bergerak dalam organisasi gereja, organisasi yang berkaitan dengan agama Buddha, Konfusianisme, dan Taoisme serta organisasi pendidikan yang ada di bawah organisasi tersebut di atas dan mengikuti kegiatan PKK.

Hasil penelitian lapangan menunjukkkan responden yang menjadi anggota organisasi gereja $30 \%$, sedangkan yang menjadi anggota organisasi Buddha, Konfusianisme, Taoisme 20\%, yang menjadi pengurus organisasi pendidikan $10 \%$, menjadi anggota PKK $30 \%$, dan $10 \%$ tidak mengikuti organisasi-organisasi seperti itu. Khusus untuk organisasi pendidikan perempuan Tionghoa sangat aktif dalam yayasan Khong Kauw Hwee yang bergerak di bidang pendidikan untuk mengembangkan pengajaran Konfusianisme. Lembaga ini mendirikan sekolah taman kanakkanak, khusus untuk anak-anak Tionghoa. Pendirian taman kanakkanak (TK) ini bertujuan untuk memberikan pendidikan pada anakanak Tionghoa yang kurang mampu. Selain mengikuti organisasiorganisasi tersebut di atas, perempuan Tionghoa mengikuti kegiatan arisan yaitu arisan yang diadakan untuk perempuan yang sudah berkeluarga maupun remaja putri. Arisan ini mempunyai tujuan untuk mengakrabkan dan mempererat hubungan antara sesama warga setempat. Dalam acara arisan ini sering diisi dengan kegiatan penyuluhan yang berkaitan dengan keluarga berencana, memberikan 
keterampilan-keterampilan dan lain sebagainya (Mosse, 1996:71).

Partisipasi

perempuan

Tionghoa dalam program keluarga berencana $(\mathrm{KB})$ dipandang penting karena budaya mereka menganggap bahwa anak yang banyak akan mendatangkan banyak rejeki pula. Pandangan ini sudah tidak sesuai dengan program pembangunan yang dicanangkan oleh pemerintah. Untuk menunjang program pemerintah tersebut, perempuan Tionghoa banyak yang sudah mengikuti program keluarga berencana terutama perempuan Tionghoa yang berpendidikan dan berpikiran maju. Walaupun demikian, masih banyak perempuan Tionghoa yang belum menyadari pentingnya program keluarga berencana bagi pembangunan Indonesia. Dari temuan di lapangan $40 \%$ perempuan Tionghoa sudah melakukan program KB dengan kesadaran sendiri, 30\% melakukan program KB karena ikutikutan dan karena malu, sedangkan $30 \%$ tidak melakukan program KB. Dari seluruh responden yang telah mengikuti program KB dapat dilihat sebanyak $70 \%$ berpendidikan tinggi, sedangkan $20 \%$ berpendidikan rendah dan $10 \%$ tidak berpendidikan. Dengan demikian, partisipasi perempuan Tionghoa dalam program KB dapat diharapkan lebih baik pada masa mendatang (Mosse, 1996:73).

\section{SIMPULAN}

Dari hasil penelitian tentang kehidupan perempuan pada masyarakat Tionghoa di Kota Medan dapat disimpulkan bahwa perbedaan peran laki-laki dan perempuan merupakan pemahaman yang lahir sebagai akibat pelaksanaan tradisi dan budaya Tionghoa yang bersumber dari ajaran Konfusianisme dan Taoisme, dimana laki-laki cenderung menempati posisi ordinat, sedangkan perempuan di posisi subordinat.

Dewasa ini potensi perempuan Tionghoa di Kota Medan dalam pembangunan sangat besar. Partisipasi mereka di bidang sosial, ekonomi, politik, dan budaya tidak dapat diabaikan. Untuk mencapai keadaan seperti tersebut di atas melalui proses yang cukup lama. Hingga pertengahan abad ke-20 keadaan perempuan Tionghoa belum menggembirakan, mereka masih terkungkung dalam aturan adat yang membatasi kebebasan serta aktivitas mereka. Pada masa itu, keterbatasan aktivitras perempuan Tionghoa di bidang sosial, ekonomi, politik, dan budaya dipengaruhi oleh hal-hal yang bersifat gender. Dalam pendidikan perempuan Tionghoa tertinggal jauh dibanding dengan laki-laki, hal ini dikarenakan dalam budaya Tionghoa kedudukan perempuan berada di bawah lakilaki. Mereka tidak mempunyai hak dalam memperoleh kemajuan. Hal ini ditambah dengan adanya tradisi pingitan semakin membatasi aktivitas perempuan Tionghoa. Keadaan berubah setelah dibuka pendidikan untuk orang Tionghoa termasuk anak perempuan. Pendidikan ini telah membawa perubahan, yaitu perubahan dalam 
aktivitas perempuan Tionghoa. Pendidikan telah menumbuhkan kesadaran tentang adanya persamaan hak antara laki-laki dan perempuan, kesadaran tentang kebebasan dalam melakukan aktivitas dan mengemukakan pendapat dan lain sebagainya. Dari sinilah ketidakadilan gender mulai mendapat perlawanan, meskipun masih dalam tatanan yang bersifat politik.

Perempuan Tionghoa di Kota Medan selain disibukkan dengan urusan rumah tangga dan kegiatan ekonomi dalam memenuhi kebutuhan rumah tangga juga melakukan kegiatan-kegiatan di luar lingkup rumah tangganya dalam berbagai organisasi sosial kemasyrakatan. Mereka aktif dalam organisasi gereja, organisasi agama Buddha, Konfusianisme dan Taoisme serta organisasi pendidikan dan PKK. Selain itu mereka juga sudah aktif berpartisipasi dalam mengikuti program Keluarga Berencana (KB). Partisispasi mereka secara umum masih kental dengan corak partisipasi di sektor domestik.

\section{REFERENSI}

Darwis, Aimee. 2010. Orang Indonesia Tionghoa Mencari Identitas. Jakarta: Gramedia Pustaka Utama.

Davonar, Agnes. 2013. Kisah Hidup Queeny Chang Anak Tjong A Fie Orang Terkaya di Medan. Jakarta: Gramedia Pustaka Utama.
Koh, Vincent. 2011. I Ching Wisdom

Revealed. Jakarta: Kompas Gramedia.

Lasiyo. 1995. Ajaran Konfusianisme, Tinjauan Sejarah dan Filsafat. Lasiyo (Editor), dalam Konfusianisme Di Indonesia: Pergulatan Mencari Jati Diri. Yogyakarta: Interfidei.

Lie, Yusin. 2000. Prasangka Terhadap

Etnis China. Jakarta: Djambatan.

Moleong, Lexy J. 2005. Metode Penelitian Kualitatif. Bandung: Remaja Roskarya.

Mosse, Yulia Cleves. 1996. Gender dan Pembangunan. Yogyakarta: RIFKA ANNISA Woman's Crisis Center dan Pustaka Pelajar.

Mulyana, Dedi. 2006. Komunikasi Antarbudaya: Panduan

Berkomunikasi dengan Orang-Orang Berbeda Budaya. Bandung: Remaja Rosdakarya.

Taylor, Andrea. 2003. "What's New about 'the New Femininity' Feminism, Femininity, and the Discourse of the New" in Hecate, Vol 23(2), pp.

Vasanti, Puspa. 1990. "Kebudayaan

Orang Tionghoa di Indonesia" dalam Masyarakat dan Kebudayaan di Indonesia. Koentjaraningrat (ed.). Jakarta: Djambatan.

Hasil wawancara dengan Ibu Meimei, yang dilakukan pada tanggal 8 April 2016. 
Hasil wawancara dengan Ibu

Ngartini Huang, yang

dilakukan pada tanggal 13

April 2016.

Hasil wawancara dengan Halim Loe,

yang dilakukan pada tanggal 16 April 2016.

Hasil wawancara dengan Anggi

Prawira, yang dilakukan pada tanggal 18 April 2016. 